\title{
PENGARUH TERAPI EXPRESSIVE WRITING TERHADAP PENURUNAN KECEMASAN SAAT UJIAN SEKOLAH (Studi Kuasi Eksperimen Terhadap Siswa Kelas XI di SMA Negeri 59 Jakarta)
}

\author{
Diah Putri Ayu Purnamarini ${ }^{1}$ \\ Theodorus I. Setiawan ${ }^{2}$ \\ Dede Rahmat Hidayat ${ }^{3}$
}

\begin{abstract}
Abstrak
Tujuan penelitian ini untuk mengetahui pengaruh expressive writing terhadap penurunan tingkat kecemasan tinggi pada siswa saat ujian sekolah. Penelitian ini dilakukan di SMA Negeri 59 Jakarta pada bulan Agustus sampai dengan September 2015. Penelitian ini menggunakan peneliti kuasi eksperimen dengan bentuk Nonequivalent Control Group Design. Berdasarkan hasil uji validitas dan reliabilitas yang telah digunakan, instrumen kecemasan memiliki 62 item butir pernyataan yang valid dan memiliki koefisien reliabilitas sebesar 0.933 . Berdasarkan hasil pengujian hipotesis dengan menggunakan teknik Wilcoxon Match Pairs Test, diperoleh nilai Asymp. Sig sebesar 0.01 yang berarti nilai probabilitas lebih kecil dari nilai signifikansi $\alpha 0.05$, maka terjadinya penururan kecemasan pada siswa dengan melakukan expressive writing. Dengan demikian dapat disimpulkan bahwa $\mathrm{H}_{0}$ ditolak dan $\mathrm{H}_{1}$ diterima, yaitu dengan terjadinya penurunan tingkat kecemasan tinggi bagi siswa saat ujian sekolah yang signifikan setelah diberikan perlakuan. Terapi expressive writing dapat diterapkan oleh guru bimbingan dan konseling di sekolah sebagai salah salah satu alternatif penanganan untuk menangani siswa yang mengalami masalah dengan tingginya tingkat kecemasan saat ujian sekolah.
\end{abstract}

Kata Kunci: Terapi expressive writing , kecemasan saat ujian

\section{PENDAHULUAN}

Masa remaja disebut pula sebagai masa penghubung atau masa peralihan antara masa kanak-kanak dengan masa dewasa. Pada periode ini terjadi perubahanperubahan besar dan esensial. Sering terlihat pada periode ini anak remaja mulai meyakini kemauan, potensi dan cita-cita sendiri. Adanya kesadaran ia berusaha untuk menemukan jalan hidupnya dan mulai mencari nilainilai tertentu seperti kebaikan, keluhuran, kebijaksanaan, keindahan dan sebagainya. Anak yang digolongkan remaja adalah mereka yang berusia 13-18 tahun (Hurlock, 1981). Pada masa remaja siswa muda merasa cemas saat dihadapkan pada suatu masalah yang mendesak, seperti mengalami kecemasaan yang tinggi saat ujian sekolah. kecemasan merupakan suatu keadaan relatif namun sekaligus menjadikan tingkah laku seperti pola yang menggambarkan suatu keadaan emosional dengan memberikan kombinasi unik dari pemikiran dan perasaan yang tidak menyenangkan diikuti beberapa perubahan dengan pengaktifan susunan saraf otonom. Kecemasan ringan dapat mendorong peningkatan performa dan tingkat kecemasan ini masih tergolong normal. Namun apabila kecemasan sangat besar, justru akan sangat mengganggu (Spielberger, 1971).

\footnotetext{
${ }^{1}$ Mahasiswa Program Studi Bimbingan dan Konseling FIP UNJ, diahputriayu90@gmail.com

${ }^{2}$ Dosen Program Studi Bimbingan dan Konseling FIP UNJ, thisetiawan@gmail.com

${ }^{3}$ Dosen Program Studi Bimbingan dan Konseling FIP UNJ, d_r_hidayat@yahoo.com
} 
Berdasarkan pada permasalahan yang muncul, maka perlu adanya bimbingan dan bentuk bantuan yang dipilih dengan menggunakan teknik expressive writing. Menurut (Pennebaker, 2007) expressive writing adalah kegiatan menuliskan perasaan dan pikiran terdalam terhadap suatu peristiwa traumatis atau pengalaman emosi yang pernah dimiliki. Salah satu keunggulan dari terapi expressive writing ialah membebaskan para konseli menuangkan segala bentuk rasa kecemasaannya dalam tulisan mereka tanpa harus memperhatikan susunan kata baku atau penulisan bahasa yang baik dan benar.

Berdasarkan permasalahan yang terjadi di atas, maka rumusan masalah dalam penelitian ini adalah mengenai: "Apakah terdapat Pengaruh Expressive writing dalam Menurunkan Tingkat Kecemasan saat Ujian Sekolah Siswa SMAN 59 Jakarta?"

\section{KAJIAN TEORETIK THERAPY EXPRESSIVE WRITING}

Pennebaker dan Seagal (2013) mendefinisikan expressive writing sebagai tulisan yang mencerminkan pikiran yang jujur dan perasaan tentang pengalaman hidup otentik, dengan sisi wawasan. Expressive writing salah satu bentuk layanan responsif yang merupakan pemberian bantuan kepada siswa yang memiliki kebutuhan dan masalah yang memerlukan pertolongan dengan segera. Expressive writing dapat membantu siswa yang memiliki masalah kecemasan pada kategori tinggi saat menghadapi ujian sekolah dengan mengungkapkan perasaan serta pemikiran yang jujur, dituangkan dalam bentuk tulisan tanpa adanya aturan baku pada proses penulisan. Konsep dasar dalam expressive writing adalah ketika orang mengubah perasaan dan pikiran mereka mengenai hal yang bersifat pribadi dan pengalaman menjengkelkan yang dituang melalui tulisan. Expressive writing memiliki manfaat, (Bolton, 2005) menyatakan bahwa expressive writing membantu individu untuk memahami dirinya dengan lebih baik, dan menghadapi depresi, distress, kecemasan, adiksi, ketakutan terhadap penyakit, kehilangan dan perubahan dalam kehidupannya.

Tahapan expressive writing (Hynes $\&$ Thompson, 2006) membagi terapi menjadi empat tahap, yakni:

1. Recognition atau Initial Write

Merupakan tahap pembuka menuju sesi menulis. Tahap ini bertujuan untuk membuka imajinasi, memfokuskan pikiran, relaksasi dan menghilangkan ketakutan yang mungkin muncul pada diri konseli, serta mengevaluasi kondisi perasaan atau konsentrasi konseli. Konseli diberi kesempatan untuk menulis bebas kata-kata, frase, atau mengungkapkan hal lain yang muncul dalam pikiran tanpa perencanaan dan arahan.

2. Examination atau Writing Exercise

Tahap ini bertujuan untuk mengexplore reaksi konseli terhadap suatu situasi tertentu. Waktu yang diberikan untuk menulis bervariasi, 10-30 menit setiap sesi. Setelah menulis konseli juga dapat diberi kesempatan untuk membaca kembali tulisannya dan menyempurnakannya. Jumlah pertemuan berkisar 3-5 sesi secara berturut-turut atau satu kali seminggu.

3. Juxtaposition atau Feedback

Tahapan ini merupakan sarana refleksi yang mendorong pemerolehan kesadaran baru dan menginspirasi perilaku, sikap, atau nilai yang baru, serta membuat individu memperoleh pemahaman yang lebih dalam tentang dirinya. Tulisan yang sudah dibuat konseli dapat dibaca, direfleksikan, atau dapat juga dikembangkan, disempurnakan, dan didiskusikan dengan orang lain atau kelompok yang dapat dipercaya oleh konseli. Hal pokok yang digali pada tahap ini adalah bagaimana perasaan penulis saat menyelesaikan tugas menulis dan atau saat membaca.

4. Aplication to the Self

Pada tahap terakhir ini, konseli didorong untuk mengaplikasikan pengetahuan baru dalam dunia nyata. Konselor atau terapis 
membantu konseli mengintegrasikan apa yang telah dipelajari selama sesi menulis dengan mereflesikan kembali apa yang mesti diubah atau diperbaiki dan mana yang perlu dipertahankan. Selain itu juga dilakukan refleksi tentang manfaat menulis bagi konseli. Konselor juga perlu menanyakan apakah konseli mengalami ketidaknyamanan atau bantuan tambahan untuk mengatasi masalah sebagai akibat dari proses menulis yang mereka ikuti

\section{KECEMASAN}

Spielberger (1971) mendefinisikan kecemasan sebagai emosi berdasarkan penilaian yang memerlukan simbol-simbol, antisipasi, dan unsur-unsur ketidak pastian. Selain itu Spielberger menambahkan konsep ancaman dalam hal ini adalah penilaian subjektif dari seorang akan situasi yang berpotensi merugikan dan ancaman bagi dirinya. Kecemasan merupakan suatu keadaan yang relatif namun sekaligus juga pola abadi tingkah laku, yang menggambarkan suatu keadaan emosional dari kombinasi unik dari pikiran-pikiran dan perasaan yang tidak menyenangkan diikuti perubuhan-perubahan dengan pengaktifan susunan saraf otonom.

Vye (2006) mengungkapkan bahwa gejala kecemasan dapat diidentifikasikan melalui dalam tiga komponen. yaitu:
1. Komponen koginitif:

Cara individu menafsirkan keadaan, mereka fokus pada kemungkinankemungkinan buruk dan mengancam sehingga mereka mengalami keraguan, khawatir dan ketakutan. Cenderung untuk membayangkan kemungkinan terburuk, memperbesar kemungkinan kerusakan dan konsekuensi bencana. Selain itu mereka juga cenderung meremehkan kemampuan diri untuk mengatasi situasi. Jadi bukan hanya menafsirkan situasi sebagai suatu yang sulit, atau mengancam, mereka juga melihat dirinya kurang mampu untuk mengatasi masalah itu.

2. Komponen Fisik:

Gejala kecemasan pada komponen fisik berupa gejala yang dirasakan langsung secara fisik. Gejala kecemasan pada komponen fisik mengacu pada berbagai sensasi fisiologis seperti sesak napas, detak jantung lebih cepat, sakit perut, otot tegang, dan pusing. Gejala tersebut berkaitan dengan mekanisme biologis alami yang mempersiapkan kita untuk menanggapi ancaman atau bahaya. Kadang-kadang, orang bisa menjadi bingung atau takut pada beberapa sensasi fisiologis atau gejala kecemasan.

3. Komponen Perilaku:

Gejala kecemasan pada komponen perilaku melibatkan perilaku atau tindakan ketika seseorang mengalami kecemasan seperti overcompensating atau overcontrolling.

\section{REMAJA}

Adolescence atau remaja berasal dari kata latin adolescere yang berarti "tumbuh" atau "menjadi orang dewasa" (Hurlock, 1999). Hurlock menyatakan bahwa masa remaja berlangsung sejak pra remaja (1114 tahun), remaja awal (14-17 tahun), dan remaja lanjut (17-21 tahun). Menurut Erikson remaja adalah suatu masa yang antara 
lain ditandai oleh sifat-sifat yang idealis, romantis, berkhayal, berharapan tinggi dan berkeyakinan. Dengan demikian, remaja merupakan masa peralihan dari masa anakanak ke masa dewasa dimana identitasnya akan lebih berkembang yang ditandai dengan adanya sifat dan perilaku yang khas (Gunarsa \& Yulia, 2008).

\section{METODOLOGI PENELITIAN}

Penelitian ini bertujuan untuk mengetahui efektivitas layanan expressive writing terhadap kecemasan yang akan melaksanakan ujian pada siswa SMA Negeri 59 Jakarta yang menjadi anggota kelompok. Penelitian dilaksanakan di SMA Negeri 59 Jakarta yang terletak di Jalan Bulak Timur I/ 10-11 Klender, Jakarta Timur yang dilakukan pada semester ganjil tahun ajaran 2015 -2016 di bulan Juli sampai dengan September 2015 . Metode penelitian yang digunakan adalah eksperimen. Jenis penelitian eksperimen yang dilakukan adalah Quasi Experimental Design dengan bentuk Nonequivalent Control Group Design. Desain ini sama seperti pretest-posttest control group design hanya saja sampel tidak dipilih secara random (Sugiyono, 2010: 107). Kelompok eksperimen dan kelompok kontrol akan diberikan pretest. Selanjutnya, kelompok eksperimen diberikan perlakuan sedangkan kelompok kontrol tidak diberikan perlakuan. Kemudian kedua kelompok diberikan posttest.

Proses terapi ini dilakukan dalam waktu 45 menit. Populasi penelitian ini adalah siswa SMA Negeri 59 Jakarta kelas XI. Sampel terdiri dari 16 siswa berdasarkan hasil prestest dengan kategori tingkat kecemasan yang tinggi. Pengelompokan data penelitian mengacu pada kriteria kategorisasi, dalam penelitian ini diberlakukan norma kategorisasi dengan kriteria: tinggi, sedang, dan rendah (Azwar, 2007).

\begin{tabular}{|c|c|}
\hline Kategori & Kriteria Jenjang \\
\hline Tinggi & $133 \geq X \leq 159$ \\
\hline Sedang & $107 \geq X \leq 132$ \\
\hline Rendah & $81 \geq X \leq 106$ \\
\hline
\end{tabular}

menggunakan teori Kecemasan dari Vye et.al. yang memiliki empat pilihan jawaban yaitu selalu (SL), sering (SR), jarang (JR), dan tidak pernah (TP) dengan skala Likert. Item uji coba 75 butir, item drop 13 butir dan item final 62 butir. Pengujian validitas menggunakan teknik Product Moment Pearson dan pengujian reliabilitas didapatkan hasil 0.933. menggunakan teknik Alpha Cronbach dengan bantuan aplikasi Statistical Product and Service Solution (SPSS) 17.0 for windows. Teknik analisis data yang digunakan dalam penelitian ini adalah Wilcoxon Match Pairs Test dengan menggunakan bantuan aplikasi Statistical Product and Service Solution (SPSS) 17.0 for Windows.

\section{HASIL DAN PEMBAHASAN}

Berdasarkan hasil pretest-posttest yang dilakukan pada kelompok eksperimen dan kelompok kontrol dengan masing-masing terdiri dari delapan siswa SMA Negeri 59 Jakarta didapatkan hasil sebagai berikut:

Tabel 2

Rata-rata Capaian Skor Kecemasan

\begin{tabular}{ccccccc}
\hline $\begin{array}{c}\text { Skor } \\
\text { Rata }\end{array}$ & $\begin{array}{c}\text { Skor } \\
\text { Ide- } \\
\text { Rata }\end{array}$ & $\begin{array}{c}\text { Pre-test } \\
\text { al }\end{array}$ & $\%$ & $\begin{array}{c}\text { Post- } \\
\text { test }\end{array}$ & $\%$ & $\begin{array}{c}\text { Penu- } \\
\text { runan }\end{array}$ \\
\hline $\begin{array}{c}\text { Kel. } \\
\text { Eks. }\end{array}$ & 248 & 142.37 & 57.40 & 112.12 & 45.20 & 30.25 \\
& & & & & & \\
Kel. & 248 & 139.25 & 56.14 & 127.25 & 51.31 & 12 \\
Kontr. & & & & & & \\
\end{tabular}

Table 3

Perbandingan Capaian Skor Per Dimensi 


\begin{tabular}{|c|c|c|c|c|c|c|c|}
\hline \multirow[b]{2}{*}{$\begin{array}{l}\text { 능 } \\
\stackrel{0}{\Xi} \\
\frac{0}{0} \\
\underline{v}\end{array}$} & \multirow{2}{*}{$\begin{array}{l}\overline{\overparen{J}} \\
\frac{\overrightarrow{0}}{\overline{0}} \\
\frac{\ddot{0}}{\tilde{\omega}}\end{array}$} & \multirow[b]{2}{*}{$\begin{array}{l}\stackrel{\Xi}{\Xi} \\
\text { Z } \\
\text { Z }\end{array}$} & \multirow[b]{2}{*}{ 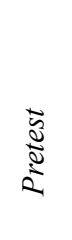 } & \multicolumn{3}{|c|}{ SKOR } & \multirow[b]{2}{*}{ 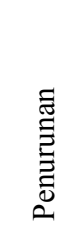 } \\
\hline & & & & $\partial^{0}$ & 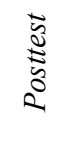 & $\partial^{0}$ & \\
\hline \multirow{7}{*}{ 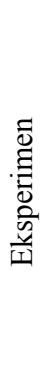 } & \multirow{7}{*}{$\stackrel{\infty}{\sim}$} & AS & 156 & 62.90 & 95 & 38.31 & 24.59 \\
\hline & & GPA & 134 & 54.03 & 122 & 49.19 & 4.84 \\
\hline & & YA & 134 & 54.03 & 99 & 39.92 & 14.11 \\
\hline & & ANI & 147 & 59.27 & 117 & 47.18 & 12.09 \\
\hline & & AMD & 134 & 54.03 & 126 & 50.81 & 3.22 \\
\hline & & KMS & 159 & 64.11 & 120 & 48.39 & 15.72 \\
\hline & & IR & 140 & 56.45 & 126 & 50.81 & 5.64 \\
\hline & & $\mathrm{AB}$ & 135 & 54.44 & 92 & 37.10 & 17.34 \\
\hline \multirow{8}{*}{$\begin{array}{l}\overline{0} \\
\stackrel{\Xi}{0} \\
\stackrel{0}{1}\end{array}$} & \multirow{8}{*}{$\stackrel{\infty}{\sim}$} & AS & 133 & 53.63 & 124 & 50.00 & 3.63 \\
\hline & & B & 137 & 55.24 & 129 & 52.81 & 2.43 \\
\hline & & MIF & 137 & 55.24 & 126 & 50.81 & 4.43 \\
\hline & & $\mathrm{JGV}$ & 142 & 57.26 & 134 & 54.03 & 3.23 \\
\hline & & RBP & 147 & 59.27 & 159 & 72.27 & 13 \\
\hline & & A & 133 & 53.63 & 127 & 51.21 & 2.42 \\
\hline & & MS & 141 & 56.85 & 132 & 53.23 & 2,62 \\
\hline & & NR & 144 & 58.06 & 131 & 52.82 & 5.24 \\
\hline
\end{tabular}

Berdasarkan hasil pretest dan posttest pada dua kelompok terdapat perubahan skor yang terjadi. Pada kelompok eksperimen, sebelum diberikan perlakuan, seluruh anggota berada pada kategori rendah. Rata-rata skor sebelum diberi perlakuan sebesar 142.37 . Sedangkan setelah diberikan perlakuan, ratarata skor menurun 30.25 mencapai 112.12, dengan tiga siswa meningkat pada kategori tinggi, dan lima siswa pada kategori sedang. Pada Kelompok kontrol, rata-rata skor sebelum perlakuan sebesar 139.25 dengan keseluruhan siswa berada pada kategori rendah. Setelah diberikan perlakuan, terdapat penurunan skor sebesar 6.5 mencapai 132.75, dengan dua siswa meningkat, tiga siswa kategori sedang dan tiga siswa lainnya tetap di kategori rendah.

Tabel 4

Data Capaian Skor Kecemasan

\begin{tabular}{cccc}
\hline Komponen & $\begin{array}{c}\text { Skor } \\
\text { Pretest }\end{array}$ & $\begin{array}{c}\text { Skor } \\
\text { Posttest }\end{array}$ & Skor \\
\hline Kognitif & 1006 & 762 & 244
\end{tabular}

\begin{tabular}{cccc} 
Fisik & 510 & 438 & 72 \\
Perilaku & 747 & 714 & 33 \\
\hline \multicolumn{4}{r}{ Terapi ini dilakukan dalam Sembilan }
\end{tabular}
sesi pertemuan sesuai dengan kebutuhan terapi. Persiapan pelaksanaan terapi dimulai dari pemberian pretest, pembentukan kelompok terapi dan perencanaan jadwal pertemuan di setiap sesi terapi. Pada penelitian ini, terapi akan diberikan kepada delapan konseli pada kelompok eksperimen, yaitu AS, GPA, YA, ANI, AND, KMS, IR, dan AB. Pelaksanaan expressive writing dilakukan dengan empat tahapan yaitu Recognition atau Initial Write, Examination atau Writing Exercise, Juxtaposition atau Feedback dan Aplication to the Self. tahap terpenting pada terapi expressive writing yaitu pada tahap menulis atau writing exercise karena bagian terpenting ketika anggota kelompok mulai menuliskan pengalaman serta perasaannya.

Berdasarkan hasil penghitungan dengan menggunakan SPSS, nilai Asymp. Sig sebesar 0.01 yang berarti nilai probabilitas lebih kecil dari nilai signifikansi $\alpha 0.05$. Dengan demikian dapat disimpulkan bahwa $\mathrm{H} 0$ ditolak dan $\mathrm{H} 1$ diterima, yaitu terjadi penurunan kecemasaan saat ujian sekolah yang signifikan setelah diberikan perlakuan. Maka dapat disimpulkan bahwa, terdapat pengaruh layanan terapi expressive writing terhadap penurunan kecemasan saat ujian sekolah siswa SMA Negeri 59 Jakarta.

Penelitian ini tidak luput dari kesalahan karena keterbatasan peneliti. Oleh karena itu ketidak sempurnaan ini sangat membutuhkan perbaikan-perbaikan kedepannya. Beberapa hal yang menjadi keterbatasan peneliti antara lain:

1. Tidak semua anggota memiliki kesenangan menulis karena sampel dipilih berdasarkan kategori kecemasan yang tinggi, sehingga tidak semua anggota dapat mengungkapkan perasaan, pikiran, dan emosi ke dalam sebuah tulisan. Oleh karena itu expressive writing tidak dapat digunakan pada setiap individu untuk mengungkapkan pengalaman traumatis. 
2. Hasil penelitian ini hanya berlaku pada kelompok penelitian dengan situasi yang tercipta saat kegiatan berlangsung, tidak dapat digeneralisasikan kepada kelompok dan situasi lain.

3. Kegiatan konseling dilakukan disaat pulang sekolah sehingga membuat anggota kelompok ingin segera mengakhiri kegiatan konseling kelompok.

4. Ketika anggota kelompok diminta berkali-kali untuk menulis timbul kejenuhan pada anggota kelompok, mereka menggunakan tidak tahu apalagi yang harus mereka tulis.

5. Terdapat faktor internal dan eksternal kecemasan dari responden yang tidak dapat dikendalikan oleh peneliti pada saat dilakukannya penelitian sehingga mempengaruhi reliabilitas hasil penelitian.

\section{KESIMPULAN DAN SARAN}

Terapi expressive writing dapat digunakan untuk membantu siswa menurunkan kecemasan saat ujian sekolah. Kecemasan yang dirasakan oleh siswa saat ujian akan mempengaruhi hasil ujian. Permasalahan yang diungkapkan dalam kelompok menuntut siswa agar mampu mengelola diri sehingga dapat menurunkan tingkan kecemasaan saat ujian sekolah.

Siswa dengan permasalahan kecemasaan saat ujian sekolah menurun pada komponen kognitif dengan penurunan skor 244, maka menandakan bahwa anggota kelompok mampu menghilangkan kemungkinan-kemungkinan negative yang muncul saat ujian sekolah dan tidak lagi meragukan kemampuan yang ada pada dirinya. Komponen fisik dengan penurunan skor 73 menandakan bahwa anggota kelompok mampu mengontrol dirinya bukan hanya kognitif akan tetapi fisik seperti menafsirkan rangsangan fisik dengan mengambil nafas panjang untuk merenggangkan otot. Komponen perilaku memperoleh penurunan skor sebesar 33, hal ini menunjukan bahwa anggota kelompok mampu melibatkan perilaku atau tidakan yang mampu mengurangi tingkat kecemasaannya.

Berdasarkan hasil uji hipotesis dengan menggunakan teknik Wilcoxon Match Pairs Test, diperoleh nilai Asymp. Sig sebesar 0.01 yang berarti lebih kecil dari nilai signifikansi $\alpha 0.05$. Hal ini berarti $\mathrm{H} 0$ ditolak dan $\mathrm{H} 1$ diterima, yaitu terjadinya penurunan skor kecemasaan siswa saat ujian setelah diberikan perlakuan berupa terapi expressive writing. Disimpulkan bahwa expressive writing dapat digunakan untuk membantu menurunkan kecemasaan siswa saat ujian sekolah.

\section{DAFTAR PUSTAKA}

Atkison, Rita L. et,al. (2000). Pengantar Psikologi I Terjemahan Nurjannah Taufiq dan Agus Dharman. Jakarta: Erlangga.

Azwar, S. (2007). Penyusunan Skala Psikologi. Yogyakarta: Pustaka Pelajar.

Bolton. (2005). Writing Cures: An Introductory Handbook of Writing in Counselling and Therapy. New York: Brunner Routledge.

Corsini, R.J. (1983). Personality Theory, Research \& Asessment. Hawai: F.E Peacock Publisher.

Echols, J.M., \& Shadily, H. (2003). Kamus Inggris - Indonesia. Jakarta: Gramedia,

Frattaroli, J., \& Thomas, M. (2011). Opening Up in the Classroom: Effects of Expressive writing on Graduate School Entrance Exam Performance. American: University of California: Jurnal American Psychological Association Vol.11.

Gunarsa, S.D., \& Yulia, 2008. Psikologi Perkembangan Anak dan Remaja. Jakarta: Gunung Mulia,

Hurlock, E.B. (1981). Developmental Psychology, A Life-Span Approach. New Delhi: Tata McGraw-Hill Publishing Company. 
Hurlock, E.B. (1999). Psikologi Perkembangan: Suatu Pendekatan Sepanjang Rentang Kehidupan. Jakarta: Erlangga.

Pennebaker, J. (2013). Expressive writing Foundation of Practice. United Kingdom: Rowman \& Littefield Education.

Pennebaker, J.W., \& Friedman, C. (2007). Expressive writing , Emotional Upheavals, and Health. In $\mathrm{H}$. Friedman and R. Silver (Eds.), Handbook of Health Psychology. New York: Oxford University Press.

Santrock, J.W. (2003). Adolescence Perkembangan Remaja. Jakarta: Erlangga.

Spielberger, C.D. (1971). Anxiety Current Trends in Theory and Research Vol. II. London: Academic Press.

Sri, H.W. (2012). Pengaruh expressive writing terhadap kecemasan mahasiswa yang sedang menulis skripsi. Jurnal Mahasiswa Universitas Surabaya, 1(1).

Sugiyono. (2010). Metode Penelitian Pendidikan: Pendekatan Kuantitatif, Kualitatif dan $R \& D$. Bandung: Alfabeta.

Supranto, J. (2001). Statistik: Teori dan Aplikasi. Jakarta: Erlanga.

Vye, C. (2007). Under Pressure and Overwhelmed: Coping with Anxiety in College, London: Preager.

Wollfe, B.E. (2012). Understanding and Treating Anxiety, an Integrated Approach to Healing The Wounded Self. Washington DC: American Psychological Association.

Wright, J. K., (2004). The Passion of Science, The Precision of Poetry: Therapeutic Writing a Review of The Literature. In G. Bolton, et.al., Writing Cures: An Introductory Handbook of Writing in Counseling and Therapy. New York: Brunner Routledge. 